\title{
ON THE EPISTEMOLOGICAL SCOPE AND SOME CONTEMPORARY IMPLICATIONS OF THE QUR'ANIC NOTION OF $\bar{A} Y \bar{A} T$
}

\author{
Patrick Laude*
}

\begin{abstract}
This paper argues that the cosmic signs or āyāt repeatedly mentioned in the Qur'an can be understood, and indeed have been understood in classical Islam, as theophanic manifestations of His Being and Qualities; hence a metaphysical intuition of their divine roots goes beyond reason as mere decipherer of the wonders of structure and mechanics of the world. By contrast, literalist reformist and modernist discourses tend to shun the Quranic evidences of Divine immanence while emphasising exclusively the distance between God and His creation. This is why most contemporary Islamic apologists of modern science understand the world as a realm of cosmogonic "signatures" rather than one of metaphysical theophany. As a response to this type of views, it is argued herein that both the reductive and problematic treatment of the Qur'an as a kind of scientific manual and, at the other extreme, the denial of the conjunction between tawhīd and the traditional Islamic concept and practice of science fail to do justice to the deeper layers of meaning of a a $\bar{a}$ t. Only a consideration of a sense of the qualitative meaning of the cosmos through a restoration of a consciousness of Divine Immanence can provide an antidote to such reductive readings.
\end{abstract}

Contemporary Islamic public discourse appears, by and large, to be primarily magnetised by the two poles of law, particularly in its social and political dimensions, and science, together with its technological applications. The first pole refers to orthopraxy, or that which defines Islam as a right "doing," which means that it is intrinsic to Islam itself as a lived reality, while being often envisaged from the primary point of view of its social-political concomitances and laws. While such focuses have been obviously very significant throughout Islamic history, what may be deemed to be representative of the last decades is the extent to which religious concerns have been increasingly and exclusively centered on such areas, arguably at the expense of intellectual endeavours in the theological and philosophical fields.

Besides this "orthopractic" principle of identity, there is another set of concerns which, while being literally extra-Islamic in and of itself, has exercised an increasingly strong pull on the Islamic psyche. This is the province of modern science and its technological fruits, a field that is powerfully attractive to many Muslims as a contemporary epistemological and axiological complement to, and sometimes validation of, the Islamic religion itself. The reasons for this overwhelming impact of modern science and technology have been many, while being likely reducible to a few salient ones. First, there is an enduring sense that, 
since the dawn of contemporary history, the Islamic world has been dominated and colonised by European powers largely as a result of its inability to keep up with the scientific and technological progress taking place in Europe and America. The focus of most Muslim thinkers lying with socio-political challenges, ${ }^{1}$ therefore with matters of power, science has been endowed with supereminent prestige in terms of responding to those challenges. Secondly, and consequently, there have been growing interpretations of Islam as a rational, if not rationalistic, religion. The premises of such interpretations can be found centuries back both in Islam itself and in Western representations of Islam. ${ }^{2}$ However, for some scholars such as William Chittick, the contemporary branding of Islam as a "rational" if not "rationalistic" religion, among "both Muslim apologists and Western scholars," should not veil that "rationalism has in fact played a more restricted role in Islamic history than many historians suggest." Although the rational streak of Islam is integral to its history, it is also hardly doubtful that, with the notable exception of the world of Islamic spirituality or tasawwuf, a decline of metaphysical and spiritual discourse in Islam has been parallel to a growing rationalisation of the religion. For such analysts, this state of affairs has left a "philosophical" vacuum which only modern science, or rather applied science, could fill. ${ }^{4}$ This largely explains the positivistic character of many Islamist discourses on science in the late $19^{\text {th }}$ and $20^{\text {th }}$ century, ${ }^{5}$ as well as, more recently, the facilitation of what Olivier Roy has characterised as the "formatting" of contemporary religion as an object of ideological consumption. ${ }^{6}$ The net contemporary result is that, by and large, formal and rational tawhìd and the authority of an arguably "monolithised" shari'ah on the one hand, and modern sciences qua technology on the other hand, have become the two legitimating and validating principles of knowledge in Muslim culture. The ideological need to bring the two together could not, therefore, but arise.

Our purpose in this context is to evaluate some arguably problematic ways in which this need has been fulfilled, but also to explore the grounds on which some contemporary Muslim intellectuals have argued, by contrast, for the recovery of the oft-neglected dimensions of the spiritual traditions of Islam with respect to the scope of a possible "Qur'anic science" of the cosmos. With this objective in mind, this paper provides a few elements of reflection on the Qur'anic notion of $\bar{a} y \bar{a} t$ as a way of engaging contemporary Islamic discourses on science and knowledge. ${ }^{7}$ One of the main steps of this reflection consists in highlighting the connection, in significant and influential segments of classical Islamic theosophic and mystical metaphysics, of the notion of $\bar{a} y \bar{a} t$ with the concept of tajalliyyāt often translated in contemporary scholarship as "Divine Self-disclosures"8 and in contrasting the implications of this connection with rationalistically inclined contemporary Islamic discourses on āya $t$ as "proofs" in the context of a scientific 
knowledge of the universe. In order to do so, one must start with the observation that such metaphysical understandings of the $\bar{a} y \bar{a} t$ - which we do not claim, however, to be representative of the whole classical tradition, was founded on both basic assertions that Divine Reality transcends the world of creation and, no doubt in a more challenging and subtle way, that It manifests something of Itself, Its Qualities, or sifät, through the cosmos. ${ }^{9}$ Hence, in classical Sufi gnosis, a metaphysical intuition of the divine roots of cosmic $\bar{a} y \bar{a} t$ tended to open onto a sense of the Divine Proximity of al-Qarìb, the All-Near. It can be argued, moreover, that this sense of an immanence of the Divine Qualities through the "signs of God," while including a strong consideration of the divine "design" of creation, ${ }^{10}$ extended beyond a mere rational deciphering of the structure and mechanics of the world, and balanced out tanzīh, or transcendent incomparability, with tashbihh, or immanent analogy. ${ }^{11}$ By contrast, most contemporary readings - whether revivalist, puritanical, or modernist ones, tend to shun the Qur'anic intimations of Divine immanence while emphasising quasi-exclusively the rational and "theological" distance between God and His creation. Thus, Muslim rationalist apologists of modern science tend to understand the world as a realm of cosmogonic "signatures" rather than one of metaphysical Self-disclosures. ${ }^{12}$ In such readings, the $\bar{a} y \bar{a} t$ are conceived as cosmic markers of a transcendent Divine Intelligence rather than as instances of Divine Presence or Proximity. ${ }^{13}$ This perspective may not be exempt from a measure of reductionism which has arguably contributed to a spiritual impoverishment of the tradition. There is only one step from such a diagnosis to the hypothesis that the rationalistic reconstruction of religion opened a vacuum in which some of the religious pathologies of our times became free to prosper. In other words, if it can be argued that the modern rationalist/scientistic point of view does not readily make room for the "presential centrality" of God, then it may follow from it that this presumed "abstraction" of the Divine may foster an overemphasis on formal literalism, rational legalism, and ideological systematisation. Indeed, some contemporary rationalist and ideological forms of Islam do not seem to approach God as an immanent "centre," most likely because they are ill-equipped to understand such a perspective otherwise than as a gross "localisation" of God, hence in their view a form of idolatry or shirk.

When considering the overall intellectual climate of contemporary Islam, it is expedient, if not fully satisfactory, to take account of four representative ways of articulating the relationship between Islam, the Qur'an and modern sciences among Muslims. First, a number of prominent Islamic thinkers circumscribe their consideration of modern sciences to their practical effectiveness, while being primarily concerned with situating those sciences within Islamicallydefined ethical boundaries. This is, for example, quite evident when considering 
the remarkable development of Islamic bio-ethics in the last decades. ${ }^{14}$ These works do not significantly address the epistemological status of contemporary sciences within the context of a reflection on the meaning(s) of Qur'anic 'ilm as knowledge of God, nor in regard to a concern for the contemporary theme of a "desacralisation" or "disenchantment" of the world. They tend to neglect, ignore or reject the qualitative cosmology implied by the Qur'anic worldview that was developed by major streams of the classical tradition through notions such as those of kursī, 'arsh, and malakūt. ${ }^{15}$ Theirs is, for all practical purposes, a contemporary scientistic cosmology that they do not articulate explicitly and ontologically to the monotheistic creed and the injunctions of the shari'ah, except in a quasiethical manner in terms of a very general reference to divine injunctions to "seek knowledge." This focus on science as pragmatic "outcome" distances itself from an obsolescent $19^{\text {th }}$ century positivism, but it remains focused on the prestige of science as a central paradigm of knowledge. For instance, the primary concern of a major reformist thinker like Abdulkarim Soroush lies with saving science from positivism, i.e. from the non-recognition of the historicity of science and its claim of empirical independence from any a priori theory. Notwithstanding this reservation, Soroush still comes to the rescue of modern science against postmodern suspicions and pre-modern "obscurantism" while limiting his own scope to an ethics of science as a quest for the proper relationship between "knowledge and justice" and for "forging a desirable connection between them." ${ }^{\prime 16}$ Similarly, other prominent Muslim intellectuals, like Tariq Ramadan, do not as much address the epistemological and cosmological implications of modern sciences as they assess the need for their moral contextualisation and ethical control. ${ }^{17}$

A second type of approach, often criticised nowadays, which appears in works such as Maurice Bucaille's best seller on The Qur'an, the Bible and Science, ${ }^{18}$ addresses the epistemological implications of the Revelation by attempting to connect the explicit teachings of the Qur'an to the discoveries of science in the way of treating the Book as a repository of scientific knowledge, the truth of which would be confirmed by contemporary scientific advances. As for the third position, characterised as "culturalist-historical" by Ibrahim Kalin, ${ }^{19}$ it tends to be defined, by contrast, by an attempt at highlighting the role of historical, sociopolitical and cultural developments in fostering Islamic science. In doing so, some of those historical approaches may even argue for the independence of the two domains of religion and science from each other. In this view of things, which remains relatively minor among scholars, the developments of medieval Islamic sciences, for example, were not directly related, in practice, to Qur'anic or Islamic principles. ${ }^{20}$ Thus, Ahmad Dallal argues in favor of a historical view of religion and science in classical Islam as discrete realities that no unity or hierarchy of knowledge could subsume under a common tree of knowledge. 
In addition to those three main approaches of the relationship between Islam and science, one must also mention a fourth position, which is not without considerable influence in North American academia and much of the Muslim world, and is best represented, by the works of Seyyed Hossein Nasr, Naquib al-Attas, Osman Bakar, and Muzaffar Iqbal, among others. This view sees the Qur'an as expressing a qualitative cosmology grounded in tawhìd which is deemed to have functioned as a paradigmatic Islamic framework for scientific research and activity.

Although the second and third types of discourse are profoundly at odds in their respective views of the scope of the Qur'an and its relationship with science, they share a common concern for giving priority to the transcendent dimension of the Divine, while upholding a shared view of the primacy of rationality. This is particularly evident when considering their respective understandings of the meaning and function of the Qur'anic $\bar{a} y \bar{a} t$. While the second perspective connects scientific knowledge to revelation in outright opposition to the third one, both outlooks tend to bypass or reject the immanent and theophanic dimensions of the $\bar{a} y \bar{a} t$, while downplaying or ignoring the connection of the latter with modes of knowledge other than rational ones, such as imagination and spiritual intuition, not to mention aesthetic perception. It can be argued, therefore, that their respective conceptions of the signs of God "upon the horizon and within their own souls (nafs)" do not prevent the possibility of a rational absolutisation of the gap between creation and its Creator. In the first case (Bucaillean approach) the $\bar{a} y \bar{a} t$ are conceived "scientifically" as divine "signatures" that allow us to infer from them the existence of a transcendent Maker responsible for the workings of creation. In this view, it would seem there is a transcendent Creator who lies beyond the workings of creation, and a creation that bears the marks of His Work. Thus, the Qur'an tells us about this Work and these workings, but although the existence of the Maker is recognisable through them, He is not thereby knowable in His Essence. The connection herein is epistemologically, indeed rationally, functional rather than ontological, and the recognition of the existence of God through or from that of the world is primarily, if not exclusively, a matter of rational and scientific correlation. It pertains to what Hussein Abdul-Raof has pointedly referred to as "number-and-science oriented Qur'anic inimitability." 1 Knowledge of God is limited to a rational/scientific recognition of His existence through a confirmation of Qur'anic data by science, and this knowledge is expected to translate into a more rationally and scientifically backed obedience to the words of revelation and religion in general.

The second type of approach appears in the works of contemporary experts like Ahmad Dallal who argue for a recognition of the independence from religion that sciences have enjoyed, in their view, in Islam. In this case, as illustrated for 
example by Dallal's contextualisation of, and meditation upon, al-Rāzī's tafsīr of the Qur'anic meaning of $\bar{a} y \bar{a} t$, what the Qur'an teaches us through the $\bar{a} y \bar{a} t$ simply amounts to a recognition of the existence, power, but also unreachability and unfathomableness, of God. There is no question that Al-Rāzì's emphases, and Dallal's critical use of them, point to one of the very significant dimensions of the matter, as best illustrated in verses such as 2:22 " $(\mathrm{He})$ Who hath appointed the earth a resting-place for you, and the sky a canopy; and causeth water to pour down from the sky, thereby producing fruits as food for you. And do not set up rivals to Allah when ye know (better)." However, as a result of this exclusively "transcendentist" outlook on the $\bar{a} y \bar{a} t$ as indicators of God's all-powerfulness and unknowableness, we see a potential chasm being opened between a religious blessed unknowingness of, and surrender to, God's Essence on the one hand, and scientific knowledge on the other hand. The more "affirmative" aspect of the $\bar{a} y \bar{a} t$ as gifts from God and benefits for mankind may to some extent "soften" the rigours of this emphasis on transcendent incomparability by highlighting a relational, indeed merciful, dimension of the Transcendent, but they do not in any explicit way open onto a sense of theophanic presence. ${ }^{22}$ All they do in a sense is to remind one of the Unfathomable Mercy of the Unknowable Essence, without making God in any way "closer" in a metaphysical sense. At any rate, this may be deemed to lead to a wider separation between faith as a non-rational knowledge, and science, as the rational investigation of creation par excellence. The point made by Dallal in his commentaries on Al-Rāzì is that the Qur'an does not provide scientific answers, nor even the principles of scientific answers, to the question of the structure of cosmic phenomena, but simply fosters a sense of awe before God's power through creation, and a blessed and grateful recognition of his being the Originator. Besides and beyond these reverential and grateful sentiments, such rejection of the concept of an Islamic science fosters a situation in which modern science would become free to develop its own cosmology and the ambience of its own empirical "creation" as it were, independently from the metaphysical and cosmological demands of tawhìd. For those who hold this view, it is, implicitly or explicitly, an opportunity for fostering a "reconciliation" between the Muslim psyche and the modern paradigm, and for claiming to rid the former of what Dallal deems to be the obscurantist, "ill-disciplined" and "imaginative" burden of a pre-modern cosmology. ${ }^{23}$

Now an argument can be made that both aforementioned views of the message of the Quran and the $\bar{a} y \bar{a} t$ do not truly consider a most meaningful aspect of the Qur'anic dimension of the divine "signs," that is their qualitative and "presential aspects." This is what will be suggested in the following pages through a reading of a few representative instances of Qur'anic $\bar{a} y \bar{a} t$, together with references to a few classical texts and pieces of spiritual exegesis. 
In order to begin this discussion we would like to highlight a crucial passage from surah al-Nahl that runs from verses 11 to 79 . In this passage a long list of $\bar{a} y \bar{a} t$ are provided, including references to livestock, palm-trees, bees, colors, death and life, the wool of animals and many more "signs." The mention of these "signs" and "gifts" is not only mirroring the dual point of view of God's power and human benefits, but it also refers to human attitudes that are, or should be, normative in response to them. It is clear, therefore, that the $\bar{a} y \bar{a} t$ are intrinsically relational. Thus, at least eight verbal forms are used to characterise the actions and attitudes that befit believers in relation and response to God's ayyāt. These are, yatafakkarün (11), from the family of fikr and tafakkur or reflection and meditation, ya'qilün (12), referring to an exercise of the intellect as link to God, yadhdhakarün (13), remembrance of God as mention or prayer, dhikr, tashkurūn (14), expression of gratitude for God's gifts, ta 'tadūn (15), divine guidance provided in and through the "signs," yu'minūn (64), faith in God through His signs, and yasma' ün (65), listening to God's signs. ${ }^{24}$ It is clear from all of those examples that intelligence, will and feelings are summoned by the $\bar{a} y \bar{a} t$. $\bar{A} y \bar{a} t$ require an integral response on the part of mankind, which makes it plain why the Qur'an considers their rejection or disdain by disbelievers as the worst of transgressions. $\bar{A} y \bar{a} t$ are an expression of Divine Mercy to mankind while marking at the same time the Rigour of God by calling for a discrimination, or a discernment, that separates those who pass this test of discernment from those who do not. This is clearly indicated by the fact, noted by Madigan, that "the verbs used in recounting the response of people to God's a $\bar{y} \bar{a} t$ are overwhelming negative." 25 This latter aspect could lead one to emphasise that the "signs" bear witness, through their aspect of rigorous discernment, to the transcendence of God. Thus, when signs are pointers to the realities which they signify while being different from them, there is a need for bridging the gap between the signifier and the signified, a need in which lies the "merit" of the believer. However, the merit attached to the response of the believers is not a mere matter of rational recognition, but one of direct, integral, one could say "holistic" contact with the āyat. This is why, according to some mystical tafsirs, only the saint or "knower by God" can truly know the depth of the $\bar{a} y \bar{a} t .{ }^{26}$ At any rate, guidance and remembrance entail much more, for example, than mere scientific investigation or deciphering, since they imply a spiritual realisation, or tahqīq. And the expression to "listen" to the signs connote both an exercise of sensory and emotional attention, and one of surrender and obedience.

When looking more closely at the different kinds of $\bar{a} y \bar{a} t$, one may distinguish three. Ayāt can be tadhkirah or dhikr, ayyat bayyanāt that is clear and unambiguous signs, and finally mithāl or amthāl, that is akin to similitudes and analogies. First, the $\bar{a} y \bar{a} t$ are often defined as dhikr or tadhkirah. The natural phenomena are 
therefore reminders of the Divine and reminders of the pre-existential covenant of God with mankind. It is said in Surah al-A'rāf that when God "drew forth from the Children of Adam - from their loins - their descendants, and made them testify concerning themselves, (saying): 'Am I not your Lord ?' (Alastu birabbikum?) They said: 'Yea! We do testify!' (This), lest ye should say on the Day of Judgment: "Of this we were never mindful" (7:172). In this context, the $\bar{a} y \bar{a} t$ bring about a process of inner recollection of God by means of his "signs." The exteriorisation of God as $a z$-Zāhir through His āyāt calls for an interiorisation, an intimate recollection of God, a coming close to God on the part of mankind through $d h i k r$. This intimate recollection is diversely characterised, in its various modalities, as thinking, reflecting, remembering, listening and so forth. Moreover, this interiorisation must translate into ways to relate to the greater cosmos, as well as to any aspect of the world, human and non-human, that surrounds mankind. Thus in the verses, "the heaven He raised and imposed the balance (al-mizzann). That you not transgress within the balance. And establish weight in justice and do not make deficient the balance." (Wa aqümū al-wazna bi-l-qisti wa là tukhsirū al-mizzān) (55:7-10). The natural $\bar{a} y \bar{a} t$ pertaining to cosmic order and balance are clearly connected, in these verses, to social, moral and spiritual teachings concerning al-mizzann, a term that suggests both equilibrium and justice. The correspondence and similitude between inner integration and outer integration is unambiguously highlighted. The cosmos participates, therefore, in the very wisdom and justice of God, to which mankind is called by virtue of its original and ontological covenant with God.

We will not comment in details on the àyāt bayyanāt, the clear signs, inasmuch as they refer generally not to the natural or cosmic signs, but rather to the prophecies, miracles and prodigies brought by and through the prophets "by the permission" and through the acts of God. Like Lut (29:35) and other prophets before them, Moses is endowed "with clear signs" (2:92) and Jesus is given "clear signs" (2:97), and God sends "manifest signs to his servant" (57: 9). The "clarity" refers, therefore, to the directness of the "revelation" of a aya t bayyanāt as coming from God, without even the illusory mediation of secondary causes. In this sense, the Qur'an itself is, first and foremost, an äyat bayyānat, as testified in the second verse of its second surah: "This is the Book; in it is guidance sure, without doubt, to those who fear God" (2:2). Notwithstanding the privilege of "clarity" of the $\bar{a} y \bar{a} t$ bayyana $t$, all "signs" are ultimately "designed" to enter the realm of evidence and become "manifest," as testified by the verse "soon will We show them our Signs in the (furthest) regions (of the earth), and in their own souls, until it becomes manifest (yatabayyan) to them that this is the Truth" (41:53).

From our present point of view, however, the most important aspect of the $\bar{a} y \bar{a} t$ is their frequent kinship with the similitudes or analogies, in Arabic amthāl. First 
of all, it bears pondering that the Qur'an often uses natural and cosmic $\bar{a} y \bar{a} t$ in order to highlight analogies between orders of reality. In verse 7:57 for example, we read that "He it is Who sendeth the winds as tidings heralding His mercy, till, when they bear a cloud heavy (with rain), We lead it to a dead land, and then cause water to descend thereon and thereby bring forth fruits of every kind. Thus bring We forth the dead. Haply ye may remember." Thus, bringing dead land back to life by rain is connected, in several places, to God's power to resurrect the dead and to renew creation. It therefore denotes the power of God, but also a similitude between levels of reality, here the terrestrial, biological, and the celestial or eschatological. The metaphysics of the $\bar{a} y \bar{a} t$ is connected to a metaphysics of the amthāl, a metaphysics of analogy. Three points must be emphasised in this respect. First, on the most elementary level, the $\bar{a} y \bar{a} t$ as amthāl are means of divine pedagogy. The Qur'anic God teaches mankind through parables that involve analogies between realities, the lowest being obviously accessible to all while the highest pertain to divine actions, mysteries or spiritual dispositions. Now this pedagogical function is not merely metaphorical, or even allegorical, since it directly flows from metaphysics and cosmology. In other words, analogy is the fundamental law of reality. This type of understanding is one developed, for example, by Ghazālī in his Mishkat al-Anwār. Consonant with the pervasive premodern view that sees the terrestrial world as mysteriously connected to other worlds of meaning beyond it, Ghazāli expounds a metaphysics of similitude that is founded on the Qur'anic distinction between the world of dominion, 'alam al-malakūt, and the world of manifestation, 'alam al-shahädah. This distinction entails a rigorous law of correspondence or similitude between the two worlds. It is presupposed by the unity of the Real, tawhild, as well as entailed by the cosmogonic principle of a descent from the highest degrees of being to the lowest ones. Ghazāli articulates it this way: "The visible world comes forth from the world of dominion just as the shadow comes forth from the thing that throws it, the fruit comes forth from the tree, and the effect comes forth from the secondary cause. The keys to knowledge of effects are found only in their secondary cause. Hence, the visible world is a similitude of the world of dominion." ${ }^{27}$ Two further points are, moreover, important to underline here: firstly, tawhìd refers to one single God, as opposed to two, three or a thousand, but also to the exclusive and inclusive Reality of God, as expressed by the Names al-Ahad and al-Wāhid. Secondly, the process of creation is also one through which everything that is manifested must have to be present in a more essential way in the Principle of its manifestation. And this means, therefore, that the lower levels of manifestation always point to higher ones as their more "real" degree of being. Therefore, to know the $\bar{a} y \bar{a} t$ amounts to knowing God because there is nothing knowable in them that is not God's. Now, such a view is not easily aligned with dominant 
contemporary religious and scientistic understandings. It challenges the ordinary religious consciousness that postulates a quasi-absolute gap between God and the world and treats the latter as a "scientific" handicraft of God, and it also contradicts the scientistic paradigm since the prevailing concept of contemporary science that originated in the modern West denies, for all methodological purposes, the reality of that which transcends the observable and quantifiable layers of the universe.

Now, much has been made in puritanical and reformist circles of the Qur'anic axiom that "only God knows," and this has not uncommonly led to the perilous conclusion that mankind can know nothing outside of scriptures, at least when it comes to metaphysics and theology. Thus, verses stating that God "knows" and man "knows not" are often used in order to illustrate such theses. Given the pedagogical function of amthāl as $\bar{a} y \bar{a} t$ that was highlighted above, one may be arrested by the explicit Qur'anic statement according to which mankind is ignorant when it comes to similitudes. Verse 74 of surah 16 asserts that men themselves must not "strike analogies" with God because "they do not know," and only God knows how to "strike" them. It might be misleading, however, to read this verse as an absolute statement of human ignorance. What it may suggest rather, is the vertically descending direction of the gift of being and meaning. In other words, the continuity between levels of reality, or the analogies that connect them, cannot be a result of human deductions, speculations or hypotheses, but rather one of ontological necessity, coming from God, as it were. On the one hand, it is Revelation that "teaches" signs and similitudes, on the other hand the latter are inscribed in the very structure of reality. What this means is that human reason and discourse are not the foundations of analogies, without for that lessening the need for a human receptivity to Divine teachings, intimations and grace. Such receptivity entails an existential and spiritual motion of coming closer to God's presence that is the pre-condition for the theophanic unfolding of the $\bar{a} y \bar{a} t{ }^{28}$

In order to read deeper into this meaning of the immanence of God's Qualities through $\bar{a} y \bar{a} t$, it may be helpful to look at a very rich passage from the Qur'an. This passage runs from verse 63 to 73 of the Surah al-Wäqi'ah: "Have you considered what you sow? Is it you that cause it to grow, or are We the causers (az-Zāri' 'ün) of growth? If We pleased, We should have certainly made it broken down into pieces, then would you begin to lament: Surely we are burdened with debt: Nay! we are deprived. Have you considered the water which you drink? Is it you that send it down from the clouds, or are We the senders? If We pleased, We would have made it salty; why do you not then give thanks? Have you considered the fire which you strike? Is it you that produce the trees for it, or are We the producers? We have made it a reminder and an advantage for the wayfarers of the desert. Therefore glorify the name of your Lord, the Great." (56:63-73) 
The immanence of God to creation is presented on three different levels through the $\bar{a} y \bar{a} t$ of sowing, rain and wood. Irrespective of the sequential presentation of these three $\bar{a} y \bar{a} t$ in the Book, we can discern three degrees of impact of Divine immanence. There is, on the most elementary level, that of the second $\bar{a} y \bar{a} t$, a clear reference to the incapacity of humans to produce natural phenomena such as rain, of which God is the true cause, which brings back humans to a sense of ontological dependence. Secondly, even when considering the productive actions of man (like rubbing wood to make fire) one must be led to realise that they depend upon the properties given by God to the materials used by mankind. Finally, and most radically, even the actions of man himself have God as agent: man is not the real agent in "sowing" but it is in fact God who sows, and is the Sower, $a z$ Zāri'. We can see here three deeper and deeper degrees of Divine immanence. At a first level God is mostly a transcendent Cause. On the second level, He is also a transcendent Cause but He inspires man, as it were, by providing him the means of his actions. At the third degree He is clearly the only immanent Agent through His af' $\bar{a} l$, and not only as transcendent Creator. The reference to the possibility of the reduction of the seeds in powder, a striking image of the return to nothingness, suggests the Divine Power to sustain everything into creation, and the occasionalist interpretation of khalq al-jadid that is to be found in the works of not a few Muslim theologians.

The strong immanentist bent of Qur'anic $\bar{a} y \bar{a} t$ is further buttressed by a suggestive verse that evokes the flight of birds in the sky: "Do they not see the birds held in the atmosphere of the sky (fí jawwi as-samā'i) ? None holds them up except God. Indeed in that are signs for a people who believe (inna fì dhālika la-ayyātin li-qawmi yu'minūna)." (16:79) When meditating upon this verse one can infer that the $\bar{a} y \bar{a} t$ is not about a physical statement but refers, rather, to a metaphysical and spiritual reality. To understand this $\bar{a} y \bar{a} t$ scientifically, or merely physically, would actually lead one to cast doubt on the very point made by the Qur'an, since it appears to imply an ignorance of the law of gravity. In other words, it is not only that the physical laws created by God support the birds, as some tafsirs indicate: they are supported by none but God Himself, ill'Allāh. Secondly, this verse shows that a purely rational understanding of the laws of nature on the basis of physical sciences does not provide the fundamental key to the meaning of creation. The latter can only be recognised to be a mysterious but efficient Divine Act of being that sustains creatures into existence. There is no secondary cause that could be metaphysically isolated, as it were, from the primary Cause. Thirdly, this Cause is not only rationally and chronologically anterior, but also and above all metaphysically foundational at all times and in all places. As a consequence, the Qur'an suggests that the key to God-consciousness is a sense of Presence of the All-Powerful and All-Merciful 
everywhere and at any time, not a mere rational position of a First Cause which would function as a supreme technologist of the workings of Creation, while being cast aside as soon as the serious business of doing science begins. ${ }^{29}$

The sense of presence inherent to such evocations of the $\bar{a} y \bar{a} t$ is further suggested by the articulation of Unity and multiplicity implied by some Qur'anic verses. Thus in the following verses: "Lo! In the creation of the heavens and the earth and (in) the difference of night and day are tokens (of His Sovereignty) for men of understanding, Such as remember Allah, standing, sitting, and reclining, and consider the creation of the heavens and the earth, (and say): Our Lord! Thou createdst not this in vain. Glory be to Thee! Preserve us from the doom of Fire." (3:190-191). First of all it is important to note that the meditation on this $\bar{a} y \bar{a} t$ is the characteristic of those who are referred to as $\bar{u} l \bar{u}$ al-albāb and dhäkirūn. The first term, which is frequent in the Qur'an, includes the plural of lubb which refers in Arabic to an inner intelligence that suggests a penetrating and intuitive intelligence rather than rational abilities stricto sensu. As for the term dhäkirūn, it clearly refers to remembering God in mentioning Him in prayer, although this kind of prayer is obviously not restricted to the canonical salat since the latter does not involve any "reclining" and cannot nor should be performed at all times. Finally, the word for "in vain" is $b \bar{a} t i l$, which refers to something that has no substance and reality, by contrast with the Real, al-Haqq. The alternation of days and nights is one of the $\bar{a} y \bar{a} t$ mentioned on several occasions in the Qur'an. It alludes to one of the fundamental aspects of cosmic existence, one that implies order, complementarity, correspondence between outer and inner rhythms and needs and, above all perhaps, a reflection of eternity through the cyclicity of time. What is striking herein is that this alternation, with all that it entails, is related, on the side of human receptivity, to those who "remember God standing, sitting and lying," therefore throughout the various stages of the cycle of daily existence. While the duality of day and night proceeds from the Unity of the Creator, the multiplicity of human daily "states" is so to speak reabsorbed into the tawhìd of remembrance. Multiplicity and alternations flow from Unity and reproduce it through their rhythm on their own level. At the same time Unity remains, through human recollection, the metaphysical leitmotif underlying the rhythm of its manifold manifestations, as the permanent dhikr that connects temporality to Eternity, and plurality to Oneness. Those who remember God are keenly aware of qualitative differences in creation, beginning with temporal ones, against the background of a heightened awareness of the One here and now. This example demonstrates how the $\bar{a} y \bar{a} t$ may function not only as rational clues for the existence of the Creator, but as theophanic reminders of Divine Unity within creation. This aspect of multiplicity within Unity is evidently central in the a $\bar{y} \bar{a} t$ par excellence, which is the Qur'an. Let us note that it manifests itself 
both horizontally, in the diversity of verses, and vertically by the multiplicity of degrees of meaning. A number of authenticated ahädith refer to the principle that each of the verse or $\bar{a} y \bar{a} t$ of the Qur'an has four different meanings. These meanings are referred to as literal or external (having to do with the "back" of the verse or zāhir), inner (referring to the "belly" or "inside" - bätin), pertaining to the "limit" (hadd) and finally connected to the "point of ascension" or matlā'. ${ }^{30}$ Inasmuch as the concept of āya t corresponds to both Qur'anic verses and natural phenomena or "signs" - whether external or internal - one may be prompted to ask whether such degrees of meaning might have some validity when applied to the latter. Within the mystical tradition of Islam, some commentators of the Qur'an such as al-Barrajān have directly connected the three domains of manifestation of the signs of God, that is the Book, the cosmos and the soul (nafs), in a simultaneous "higher reading" of all three. ${ }^{31}$ While it is quite evident that such phenomena can be taken "literally" as "phenomena," that is literally as "appearance" or manifestation, and while it is no less evident that such phenomenal manifestations are of necessity inscribed within ontological and spatio-temporal limits that make them different from each other, it may be helpful to raise the question of the possible status and meaning of what could be considered the bätin and the matla" of phenomena "on the horizon" and "within the soul." Now the notion of an inner meaning of cosmic phenomena, a bātin, is clearly relevant to our topic, since it is directly connected to our prior discussion of the amthāl as illustrated by Ghazālī's metaphysics of analogy. In other words, any higher level of being includes the battin of a phenomenon situated on a lower ontological level. God "stands above" each creature in the sense that $\mathrm{He}$ is the Ultimate Meaning of each of them, both as Essence - because there is none other than the Essence, and as Quality or Name - because each creature makes one taste God through being a reflection of the latter.

As for the matla', its ascentional orientation highlights the transfer of the visible sign into the invisible. By contrast with the hadd that delimits each $\bar{a} y \bar{a} t$ within its own exclusive reality, the matla' ' envisions it from the point of view of its analogical openness. It has therefore to do with tashbīh, resemblance in difference, by contrast with incomparability that is akin to hadd. These alltoo briefly sketched distinctions would seem to justify encompassing all the various instances of $\bar{a} y \bar{a} t$ under the generic meaning of theophany, or "divine manifestations." Moreover, the Qur'anic attribution of the term āya t to the verses of the Qur'an itself, which Muslims consider to be the Word of God, would lead one to consider that the "sign" can indeed be theophanic. The fact that Muslims consider the recitation of the $\bar{a} y \bar{a} t$ as spiritually transformative, by contrast with their translations in other languages, cannot be simply ascribed to their divine origin but also, and therefore, to "something" at work in them that lies both 
beyond them, and is still inherent to their very being. Thus, it is plausible that Qur'anic $\bar{a} y \bar{a} t$ are not simply external markers of meaning, or mere references to the transcendence of God, but that they do entail both theophany and theurgy, the manifestation of divine power at work through a spiritually transformational process.

This theophanic aspect is confirmed by a uniquely significant use of the term $\bar{a} y \bar{a} t$ in the Surah An-Najm. During the celestial voyage alluded to in these verses, the Prophet is said to have seen the "greatest signs of His Lord (Laqad raa min $\bar{a} y \bar{a} t$ rabbihi al-kubrā)" (53:18). However, it is striking to consider that these signs are not even described in any way, as appear to transcend the means of perception and criteria of knowledge of terrestrial existence. In other words, the "greatest $\bar{a} y \bar{a} t "$ are direct theophanic manifestations of the Divine Reality that, in this particular case, surpass any human formal characterisation. These "signs" are indeed manifested, and still ineffable, as indicated by the wonderfully elliptical Qur'anic statement, "And He revealed to His servant what He revealed (Wa awha ilā abdihi $m \bar{a}$ awhā)." (53:10) $)^{32}$

In order to return to the critical framework of our inquiry we would like to suggest that much of Islamic contemporary discourses seem to be primarily determined by the modern prestige of "facts," meaning that which is "reified," whether as actions or phenomena. This particular emphasis, with the specific mindset that it presupposes and that it fosters, resonates with the concerns of a number of Muslim thinkers and scientists influenced by the modern Western outlook, one that is primarily interested in accounting for the biological, chemical or physical structure of phenomena. Although it cannot do away with the measure of moral and even spiritual intentionality that is inherent to the religious orientation as such, this type of phenomenal and formal emphasis may tend to obscure the ultimate finality of the latter, which has been traditionally understood, particularly in the inner dimensions of the tradition like tasawwuf, as a "coming closer to God." By contrast with the classical view that aligned human spiritual intention and divine grace, contemporary religion does run the risk of turning into a formal technology, as science does translate into a technology of production. Thus, the contemporary religious mindset of a portion of Muslim scientists may be considered largely "indirect" in its focus on the Ultimate inasmuch as it identifies with a sense of exclusive transcendence that can confine to rational abstraction and formalist conformity, and therefore potentially to ideological and political appropriation. This would imply moving away from the internal meaning of Islam as surrender to an "ideological" label of formal conformity.

In conclusion, one may see plausible reasons to understand the Qur'anic verse "Do not sell my $\bar{a} y \bar{a} t$ at a small price" (2:41) as an invitation not to reduce $\bar{a} y \bar{a} t$ to 
the single dimension of rational or scientific proof, but on the contrary to ponder their depth and integral significance. The latter would allow for an understanding, and a spiritual and moral consideration, of a dimension of Divine proximity. This is no doubt what the fourteenth century commentator Al-Kāshānī had in view when he refers, in his tafsir , to the signs "not to sell at a small price" as to "those indicating the self-disclosures of My essence and attributes." 33 Let us consider further, in this connection, that for Ibn 'Arabi, as William Chittick has shown, the signs are the denotations (dalälät) of the Real. ${ }^{34}$ In other words, they are not simply the connotations (mafhümät) of God, as they are in most of modern Islamic thought. Denotation refers a sign to its meaning, while connotation refers to associated meanings. The cosmic signs of a type of "scientism" that might be espoused by some secularised Muslim scientists connote God, but they do not denote Him. In this distinction lie crucial differences as to how they may envisage the $\bar{a} y \bar{a} t$ and their function in the Islamic consciousness. One of them rests with the meaning of beauty as a denotation of God, since "God is beautiful and He loves beauty." This appears in full light in the verses "And ye have a sense of pride and beauty in them as ye drive them home in the evening, and as ye lead them forth to pasture in the morning. And there is beauty (jamāl) for you when you bring them in and take them out." (16: 5-6) This beauty "for" mankind is a direct experience of God's Mercy in the form of something that is not reducible to rational understanding nor practical benefits. It is of the nature of something more immediate and more spiritually intimate.

These considerations invite us to highlight in fine a few general orientations that may be relevant to the mission of educational and socio-cultural institutions. The first lies with the need to cultivate a holistic education that does not isolate the rational and the scientific from the aesthetic and the "affective" in the deepest sense of the term. This is a precondition for nurturing a receptivity to the deeper meanings of the "signs." The second point pertains to the need to design educational curricula that highlight the richness and diversity of the Islamic intellectual traditions, thereby parrying the misguided reduction of Islamic and Qur'anic discourse to contemporary ideological trends and agendas. A third aspect relates to the high significance of spiritual and moral training as a necessary informing principle of any intellectual and scientific endeavours. This does not simply mean tracing protective ethical boundaries around human activities, but fostering a sense of tawhi d as consciousness of Unity in all areas of human activities. This would presuppose a re-centering of religious consciousness on the ultimate beauty or ihsān of the tradition. Fourthly, the educational cultivation of this consciousness cannot be achieved without a harmonious blend of contemplative education through prayer and intellectual maturation through mental exercise, discipline and argumentation. 
As a fifth point, an increased reverential attention to the function and meaning of nature in human life would be part and parcel of any holistic education. This cannot only happen through furthering a respect and protection of natural sites and species but also, and above all, through rediscovering the ways in which the terrestrial "garden" is a reflection and, for believers, a faint prefiguration of the celestial one. Finally, the various dimensions of inner development that we have just sketched must be buttressed by the nurturing of a general ambience of collective harmony and mizān; without such an ambience made of sense of respect for others, justice, and peace, many efforts may fail to translate into the highest personal potential of realisation.

The relationship between $\bar{a} y \bar{a} t$ and spiritual intimacy is no better encapsulated than in the already mentioned verse: "We will show them Our signs in the horizons and within themselves until it becomes clear to them that it is the truth. But is it not sufficient concerning your Lord that He is, over all things, the Witness?" (41:53) So even though the "signs" play a central role in the knowledge of God, it appears that the greatest, deepest and "sufficient" (yakfi) proof lies beyond proofs since it is the very and only Selfhood that witnesses the "proofs" and is indeed proof of itself, the One who "cometh in between the man and his own heart (bayna al-mar' $i$ wa qalbihi)" (8:24) and is "nearer to man than his jugular vein (aqrab ilayhi min habli al-warid)." (50:16)

\section{Notes}

* Professor Laude has been teaching at Georgetown University since 1991. A former fellow in philosophy at the Ecole Normale Supérieure in Paris, he earned a Master's degree from the University of Paris IV Sorbonne in 1982, and a Ph.D. from Indiana University in 1985. Professor Laude's scholarly interests and output lie in comparative mysticism and Western representations and interpretations of Islamic and Asian spiritual and wisdom traditions. He has authored over ten books and monographs including: Pathways to an Inner Islam, Albany: SUNY Press, 2010, Louis Massignon: The Vow and the Oath, London: Matheson Trust, 2011, Divine Play, Sacred Laughter and Spiritual Understanding. New York: Palgrave McMillan, 2005, and Singing the Way: Insights in Poetry and Spiritual Transformation. Bloomington, Indiana: World Wisdom, 2005. He has also published numerous articles in academic journals such as Studies in Spirituality, Philosophy East and West, Hikma, Sophia, Revue des sciences philosophiques et théologiques, and La Revue Théologique de Louvain. He can be contacted at laudep@georgetown.edu.

1. This has even resulted in what the Islamicist Eric Geoffroy has diagnosed as a "rationalism induced by the inferiority complex of the ex-colonized." Eric Geoffroy, L'islam sera spiritual ou ne sera plus, Paris, Le Seuil, 2009, 75.

2. This was particularly true during the Enlightenment. The case of Voltaire is quite representative of this way of understanding Islam, often in contradistinction with Christianity. "In his Les Moeurs et l'esprit des nations (1756) he (Voltaire) 
considered Muhammad an important political thinker and praised Islam as a 'rational religion', considering it more tolerant of other faiths than Christianity had been." Diane Morgan, Essential Islam: A Comprehensive Guide to Belief and Practice, Greenwood, 2010, 99.

3. William Chittick, Science of the Cosmos, Science of the Soul, OneWorld, Oxford, 2007, 95.

4. Thus Richard K. Khuri has argued that science, in much of Islamic discourse, has been understood in mainly mechanistic terms, this "mechanistic" outlook not having been without affecting the understanding of religion itself. "Modernity itself is thus also seen in mechanistic terms; for rather than grasp its rational and scientific components in their variety and richness, not to mention the moral values underlying it, urgency and haste reduce modernity to its most visible aspects: technological and economic advancement, and democracy, themselves reduced, as we have just seen, to mechanisms. So mechanism comes to dominate the Arab-Muslim reformist spirit insofar as it strives towards revitalisation along Western lines (regardless of whether this is accompanied with moral-religious conservatism or not)." In Religion and Political Structures: From Fundamentalism to Public Service, edited by John T. Ford, Robert A. Destro, Charles Richard Dechert, The Council for Research on Values and Philosophy, Washington DC 2005,41 .

5. In order to illustrate his point that "the positivistic understanding of science is shared by most Muslim thinkers in the late nineteenth and twentieth centuries", Ahmad Dallal quotes Hasan al-Bannā's assertion that "Islam does not reject science; indeed, it makes it as obligatory as the acquisition of power, and gives it its support... The Qur'ān does not distinguish between secular and religious science, but advocates both." (Ahmad Dallal, Islam, Science, and the Challenge of History, p.161).

6. Olivier Roy, Holy Ignorance: When Religion and Culture Part Ways, Columbia University Press, 2010.

7. The correlation between the Islamic concept of science and the Islamic concept of $\bar{a} y \bar{a} t$ has been clearly articulated by Muzaffar Iqbal: "Given these inherent relationships between God, humanity, and nature, it is impossible in Islam to conceive of nature as an independent self-subsisting entity. Likewise, science as an organised enterprise that studies and explores the natural world - cannot be conceived as a separate entity which has to be somehow externally related to Islam. In fact, the much-touted lack of separation of state and religion in Islamic polity is applicable to all other domains, as Muslim believe that Islam is not merely a set of commandments and rituals but a complete way of life, encompassing all domains of knowledge and human activity. This worldview is based on an uncompromising insistence on Tawhid, the Oneness of God, a ubiquitous concept in Islamic thought that unifies all realms of knowledge, making them branches of the same tree. Difficult as it may be for the modern Western mind - accustomed to regarding religion solely as set of personal beliefs - to understand this aspect of Islam, it is impossible to construct a relationship between Islam and science or any other domain of knowledge - as a relationship between two distinctively separate entities ... it is a relationship that is inherently inseparable from the wellarticulated concept of nature as a Divine Sign." Muzaffar Iqbal, The Making of 
Islamic Science. Islamic Book Trust. 2009, 10.

8. See William Chittick, The Self-Disclosure of God: Principles of Ibn Al-'Arabi's Cosmology, State University of New York Press (Suny Series in Islam), 1997.

9. This is, of course, in direct opposition to the Mu'tazilite reduction of Qualities, or Attributes, to the transcendent Essence. As Nader El-Bizri has rightfully noted, "by reducing the attributes to the essence, the Mu'tazila seemed to deny worshippers the object of their praise, exaltation and piety." The Cambridge Companion to Classical Islamic Theology, edited by Tim Winter, Cambridge University Press, 2008, 124.

10. Thus, a mystic like Ghazālī could praise the science of structural anatomy as a way of recognising "divine governance": "Indeed, on one can study the science of anatomy and the marvelous uses of the organs without acquiring this compelling knowledge of the perfect governance of Him Who shaped the structure of animals, and especially that of man." Al-Ghazali's Path to Sufism-his Deliverance from Error al-Munqidh min al-Dalal, translated by R.J. McCarthy, Fons Vitae, 2000, 29.

11. On this necessary but precarious "balance" see the chapter "Beyond Ideology" in William Chittick, Science of the Cosmos, Science of the Soul, 59-74.

12. Thus, this declaration of Al-Afghani: "Those who forbid science and knowledge in the belief that they are safeguarding the Islamic religion are really the enemies of that religion. The Islamic religion is the closest religion to science and knowledge, and there is no incompatibility between science and knowledge and the foundation of the Islamic faith." Quoted in Nikki Keddie, Sayyid Jamal al-Din "al-Afghani": A Political Biography, University of California Press, Berkeley, 1972, 104-5.

13. "Seven hundred and fifty verses of the Quran ... exhort believers to study Nature, to reflect, to make the best use of reason in their search for the ultimate, and to make the acquiring of knowledge and scientific comprehension part of the community's life." Muhammad Abdus Salam, Renaissance of Sciences in Islamic Countries, World Scientific Publishing, Singapore, 1994, 95.

14. See for example Abdulaziz Sachedina, Islamic Biomedical Ethics: Principles and Application, Oxford University Press, 2011.

15. For a study of this classical cosmology see Seyyed Hossein Nasr, An Introduction to Islamic Cosmological Doctrines, State University of New York Press, 1993.

16. Abdelkarim Soroush, Reason, Freedom, and Democracy in Islam, Oxford, 2000, $50-51$.

17. "The universal and comprehensive message of Islamic ethics penetrates all the sciences without exception, calling for moral consistency, but it does not confuse the latter with the autonomy of scientific methods (in themselves morally neutral)." Tariq Ramadan, Western Muslims and the Future of Islam, Oxford University Press, 2004, 60.

18. Maurice Bucaille, The Bible, the Qu'ran and Science: The Holy Scriptures Examined in the Light of Modern Knowledge, Tahrike Tarsile Qur'an, Seventh Revised Edition, 2003. Such a perspective is also highlighted in the works of highly respected and influential figures like Said Nursi.

19. Cf. Ibrahim Kalin, "Islam and Science”, Oxford Islamic Studies Online.

20. "Yet while religion dominated the moral sphere and claimed a higher rank there on 
account of the nobility of its subject matter, it did not exercise an epistemological hegemony over science." Ahmad Dallal, Islam, Science, and the Challenge of History, Yale University Press, 2010, 147.

21. Hussein Abdul-Raof, Theological Approaches to Qur'anic Exegesis: A Practical Comparative/Contrastive Analysis, Routledge, 2012, 62.

22. "A typical commentary focuses on the specific way the various aspects of the natural phenomena are arranged to maximize the benefits they offer to mankind." Ahmad Dallal, op. cit., 123.

23. Refer to Dallal's critique of Nasr's concept of "Islamic science" in Ahmad Dallal, op. cit., 174.

24. In addition to these verbal instances in the significant passage of Al-Nahl, Daniel Madigan has also noted, in other passages, the occurrence of the verbs raja' $a$ (to come back, 7:174, 43:48, and 46:27), ittaq $\bar{a}$ (to feel reverential fear, 2:187) faqiha (to know, 6:65) and yaqina (to be certain, 13:2) in conjunction with Quranic mentions of the āyāt. Cf. Daniel A. Madigan, The Qur'ān's Self-Image: Writing and Authority In Islam's Scripture, Princeton University Press, 2001, 98.

25. Daniel A. Madigan, op. cit. 102.

26. "God (...) has made His signs ( $\bar{a} y \bar{a} t)$ manifest to His friends (awliyā')", Tafsìr alTustarī, Great Commentaries on the Holy Qur'ān, translated by Annabel Keeler and Ali Keeler, Fons Vitae, 2011, p. 176. "[45:3] Truly in the heavens and the earth there are signs (āyatt) for those who believe." He said: The signs ( 'alāmāt) are for the one who has certainty (yaqin) in his heart, and who is guided by their existence (kawn) to the One who has brought them into existence (mukkawin)." Daniel A. Madigan, op. cit., 188.

27. Al-Ghazālī, The Niche of Lights, translated by David Buchman, Brigham Young University Press, 1998, 12.

28. Thus, the Tafsìr al-Tustarī comments on the verse "And He shows you His signs; then which of the signs of God do you reject?" (40:81) by connecting explicitly the ability to read the "signs" and the degree of sainthood: "God, Exalted is He, has made His signs ( $\bar{a} y \bar{a} t)$ manifest to His friends (awliya $\bar{a})$." Sahl ibn 'Abd Allah al-Tustari, Tafsir Al-Tustari, translated by Annabel Keeler, Fons Vitae, 2011, 176.

29. This is also the spiritual lesson drawn by Kashani in his tafsir, albeit on a different plane, when he understands the "birds" as intellective faculties that are detached from earthly and lower objects and exclusively "sustained" by God in the "atmosphere" of the world of spirits. Cf. Tafsìr Al-Kāshānī, Part I, translated by Feras Hamza, Fons Vitae, forthcoming.

30. For a discussion of various interpretations of these four "levels" see Kristin Zahra Sands, Sufi Commentaries on the Qur'an in Classical Islam, Routledge, 2006, 8-13.

31. Thus, Denis Gril notes that Ibn Barrajān's 'ibra or spiritual "passage" cannot be achieved without an involvement of all faculties of the soul in an interiorising reading of the Book and the world: «Ce passage ne peut s'accomplir sans un effort constant du lecteur sur lui-même par une intériorisation de la perception, des sens extérieurs vers les sens intérieurs, de la vue vers la vision (basar-basìra), car toutes les facultés de l'homme sont sollicitées pour la lecture simultanée du Livre et du monde.» Denis Gril, «La 'lecture supérieure' du Coran selon Ibn Barrağān», Arabica, tome XLVII, Brill, Leiden, 2000, 516. 
32. For a discussion of Sufi interpretations of these verses see the commentary of Ibn "Atā, which stresses the "purification" from any "state" and "station" that would entail some kind of human or egotic appropriation of the: "signs," in The Subtleties of the Ascension, Early Mystical Sayings on Muhammad's Heavenly Journey, Abū 'Abd al-Rahmān al-Sulamī, translated and annotated by Frederick S. Colby, Fons Vitae, 2006. "The verse seems to conceal more than it reveals about the nature of the experience." Frederick S. Colby, The Subtleties of the Ascension, 36.

33. "And do not sell, that is, do not exchange, My signs, those indicating the selfdisclosures of My essence and attributes, such as the sürat al-ikhläs [Q. 112] and the kursi-verse [Q. 2:255] and the like, for a small price, that is, for the paradise of your soul because of your habituation to the sensory pleasures and the reward of deeds through the affirmation of the unity of acts." Tafsìr Al-Kāshānnì, Part I, translated b Feras Hamza, Fons Vitae, forthcoming, 35.

34. William Chittick, The Sufi Path of Knowledge, SUNY Press, 1989, 92. 